\title{
Streptokinase Therapy in Acute Major Pulmonary Embolism : Effectiveness and Problems
}

\author{
J. HIRSH,* M.D., M.R.A.C.P.; G. S. HALE, $†$ M.D., F.R.A.C.P; I. G. MCDONALD, $\ddagger$ M.D., M.R.A.C.P \\ R. A. MCCARTHY,§ M.B.; A. PITT, $\|$ M.D., M.R.A.C.P.
}

[With Special Plate Between Pages 732 and 733]

Brit. med. F., 1968, 4, 729-734

Cummary: Eighteen patients with major pulmonary $\checkmark$ embolism were treated with streptokinase infused by a catheter or given intravenously. Fourteen showed clinical improvement and 12 out of 16 patients investigated showed definite angiographic improvement after 24 to 48 hours of treatment with streptokinase. The angiographic improvement following streptokinase contrasted with the lack of this in three patients after 24 hours of heparin treatment.

Resolution following streptokinase therapy was most noticeable in patients treated shortly after a single embolic episode, and was least marked in those with recurrent embolism complicated by associated cardiac or pulmonary disease. Of the four patients who failed to improve, two died and two had pulmonary embolectomy and survived.

The results suggest that streptokinase therapy is practicable provided that adequate laboratory control is available, and that it hastens early resolution in acute major pulmonary embolism.

\section{Introduction}

The dissolution of thrombi by enzymatic means has been investigated clinically and experimentally for a number of years. Experimentally it has been shown that the plasminogen activators, streptokinase and urokinase, accelerate resolution of pulmonary emboli in animals (Browse and James, 1964; Genton and Wolf, 1967a). Angiographic improvement has also been documented after thrombolytic therapy in patients with severe pulmonary embolism (Hirsh et al., 1967 ; Sasahara et al., 1967 ; Sautter et al., 1967 ; Tow et al., 1967). However, further investigations are required before the place of thrombolytic therapy in the management of acute major pulmonary embolism can be clearly defined. The evaluation of this form of therapy in acute pulmonary embolism demands consideration of the following questions: (1) Is it technically feasible? (2) Does it accelerate dissolution of the embolus and improve immediate survival ? (3) Does it reduce the incidence and severity of late sequelae?

The purpose of this communication is to report the clinical, angiographic, and haemodynamic findings before, during, and after streptokinase therapy in 18 patients with major pulmonary embolism. In addition, angiographic and haemodynamic changes after 24 hours of heparin administration are recorded in three patients.

\footnotetext{
* Second Assistant.

+ Cardiopulmonary Physician.

Cardiologist.

Research Assistant, National Heart Foundation of Australia. Mirector of Cardiovascular Diagnostic Service, Alfred Hospital,

University of Melbourne Department of Medicine and Cardiovascular Unit, St. Vincent's Hospital, Melbourne, Australia.
}

\begin{abstract}
Methods
Eighteen patients with severe pulmonary embolism proved by pulmonary angiography were treated with streptokinase (Tables I and II). Five had associated cardiac or respiratory disease (subsequently referred to as "complicated") (Table I). All were breathless and had clinical and haemodynamic evidence of pulmonary hypertension and right heart failure. Four required isoprenaline (isoproterenol U.S.P.) infusion to maintain an adequate circulation. All angiograms showed filling defects in the major pulmonary vessels with severe obstruction on both sides. The cardiac index, calculated in 10 cases, ranged from 1.2 to 4.3 litres/min./sq. m. and was less than 2.51 . in four patients (normal range 2.5 to 3.51 ). An attempt was made to assess changes in pulmonary vascular obstruction before and after streptokinase therapy (seven patients) and heparin therapy (two patients) by relating pulmonary arterial mean pressure to cardiac index. The formula used was index of obstruction $=\frac{\text { mean pulmonary artery pressure }}{\text { cardiac index }}$
\end{abstract}

Fifteen patients were treated with streptokinase within 5 to 48 hours of the presenting episode. The other three patients had progressive dyspnoea and were treated 16, 28, and 40 days after the initial episode of major embolism. Eight patients had acute recent embolic episodes and the other 10 had recurrent or progressive pulmonary embolism. Two of the patients with recent acute pulmonary embolism were investigated before and after 24 hours of heparin therapy and then studied again after streptokinase therapy. In addition one patient (not included in the Tables) was investigated only before and after 24 hours of heparin therapy.

The patients were nursed in a coronary care ward with continuous electrocardiographic monitoring and the cardiothoracic surgical team was consulted. Streptokinase was infused through a catheter, which was left in the main pulmonary artery in 17 of the 18 patients and was given intravenously in one. It was planned to continue the infusion for 24 hours, or longer if indicated on clinical and angiographic grounds.

Pulmonary angiography and pulmonary artery pressure measurements were repeated after streptokinase administration in 16 patients, in seven of whom cardiac output was also measured. Eight patients had further angiographic and haemodynamic studies before discharge from hospital. Lung function was studied in 10 patients before and after treatment, and in nine further studies were carried out one to eight months after the initial episode.

Laboratory Techniques.-Blood samples for fibrinolytic and coagulation assays were taken into siliconized glass syringes by clean venepuncture. High-spun plasma was prepared by centrifugation at $4^{\circ} \mathrm{C}$. and the coagulation assays and plasma fibrinolytic activity were monitored according to methods previously described (Hirsh et al., 1967), the following tests being used: thrombin clotting-time, prothrombin time, kaolin partial thromboplastin time, euglobulin lysis time, fibrin plate 
assay, plasma fibrinogen assay, and plasma plasminogen assay.

Brachial and pulmonary arterial pressures were recorded serially. Cardiac output was measured by the indicator dilution principle with indocyanine green injected into the pulmonary artery and sampled from the brachial artery through an indwelling Teflon catheter, and pulmonary angiograms were obtained with a rapid film changer (4-6 films per second). Lung function tests included arterial blood gas analysis by means of an Instrumentation Laboratories triple electrode system ; mixed expiratory gas $\mathrm{CO}_{2}$ was analysed by the same system and the alveolar-arterial oxygen tension difference $\left(\mathrm{A}-\mathrm{a} \mathrm{Po}_{2}\right)$ and percentage wasted ventilation (VD/VT) calculated (Comroe et al., 1962).

Treatment.-Heparin 10,000 units was given intravenously when the clinical diagnosis of major pulmonary embolism was máde, and the pulmonary angiogram was performed as soon as possible. The loading dose of streptokinase given over a period of 30 minutes was determined by the streptokinase resistance test, and this was followed by a maintenance dose of approxi- mately 100,000 units per hour. Treatment with heparin was continued throughout the streptokinase infusion and the dosage regulated to maintain the kaolin partial thromboplastin time one and a half to three times normal (normal 35-45 seconds). Heparin by intravenous infusion was continued after streptokinase had been stopped for a minimum of 10 days or until the patient was fully ambulant. Oral anticoagulants were begun about four days before stopping heparin, and were continued for a period of six months (O'Sullivan et al., 1968). Pulmonary embolectomy was performed in two patients under cardiopulmonary bypass.

\section{Results}

\section{Observations on Heparin Therapy}

Of the 18 patients treated with streptokinase, 11 were given heparin for 24 hours or more before streptokinase was started. In four, heparin therapy as judged by clotting-time control was

TABLE I.-Acute Pulmonary Embolism

\begin{tabular}{|c|c|c|c|c|c|c|c|}
\hline \multirow{2}{*}{$\begin{array}{l}\text { Case } \\
\text { No. }\end{array}$} & \multirow{2}{*}{$\begin{array}{l}\text { Age } \\
\text { and } \\
\text { Sex }\end{array}$} & \multicolumn{2}{|c|}{$\begin{array}{l}\text { Duration of Symptoms } \\
\text { before S.K. Therapy from }\end{array}$} & \multirow{2}{*}{ Treatment } & \multirow{2}{*}{ Clinical Result } & \multirow{2}{*}{ Angiographic Result } & \multirow{2}{*}{ Comment and Outcome } \\
\hline & & $\begin{array}{l}\text { 1st Clinical } \\
\text { Episode }\end{array}$ & $\begin{array}{l}\text { Most Recent } \\
\text { Episode }\end{array}$ & & & & \\
\hline
\end{tabular}

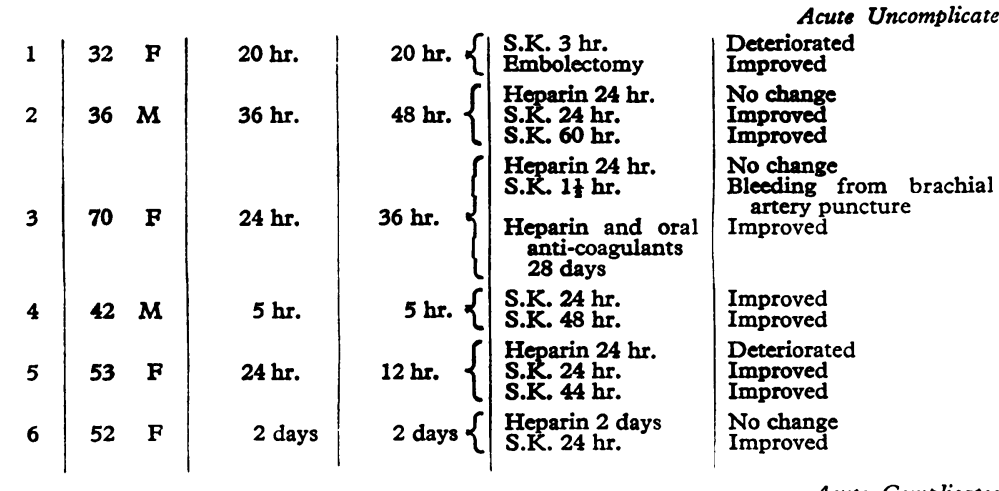

\begin{tabular}{|c|c|c|c|c|}
\hline 7 & $55 \mathrm{M}$ & $11 \mathrm{hr}$. & $18 \mathrm{hr}$. & $\begin{array}{l}\text { S.K. } 24 \mathrm{hr} . \\
\text { S.K. } 48 \text { hr. and } \\
\text { heparin } 24 \mathrm{hr} .\end{array}$ \\
\hline & $74 \quad F$ & $4 \mathrm{hr}$. & $4 \mathrm{hr}$. & $\begin{array}{l}\text { S.K. } 9 \mathrm{hr} \\
\text { Heparin } 15 \mathrm{hr} .\end{array}$ \\
\hline
\end{tabular}

\begin{tabular}{|c|c|c|c|c|}
\hline 9 & $72 \quad F$ & 21 days & $20 \mathrm{hr}$. & $\begin{array}{l}\text { S.K. } 24 \mathrm{hr} \text {. } \\
\text { S.K. } 72 \mathrm{hr}\end{array}$ \\
\hline 10 & 63 F & 5 days & $48 \mathrm{hr}$. & $\begin{array}{l}\text { S.K. } 24 \mathrm{hr} . \\
\text { S.K. } 60 \mathrm{hr} \\
\text { Heparin } 12 \mathrm{hr} \text {. }\end{array}$ \\
\hline 11 & $68 \mathrm{~F}$ & 21 days & $26 \mathrm{hr}$. & $\begin{array}{l}\text { Heparin } 24 \mathrm{hr} . \\
\text { S.R. } 24 \mathrm{hr} . \\
\text { S.K. } 72 \mathrm{hr} \text {. }\end{array}$ \\
\hline 12 & $42 \quad F$ & 7 days & $36 \mathrm{hr}$. & $\begin{array}{l}\text { Heparin } 24 \mathrm{hr} \text {. } \\
\text { S.K. } 24 \mathrm{hr} \text {. } \\
\text { S.K. } 42 \mathrm{hr} \text {. } \\
\text { Heparin } 24 \text { days }\end{array}$ \\
\hline 13 & $67 \mathrm{M}$ & 3 days & $48 \mathrm{hr}$. & $\begin{array}{l}\text { Heparin } 3 \text { days } \\
\text { S.R. } 24 \mathrm{hr} . \\
\text { Heparin } 48 \mathrm{hr} \text {. }\end{array}$ \\
\hline 14 & $58 \quad \mathrm{~F}$ & 10 days & $12 \mathrm{hr}$. & $\begin{array}{l}\text { S. K. } 24 \mathrm{hr} . \\
\text { Embolectomy }\end{array}$ \\
\hline 15 & $36 \mathrm{M}$ & 28 days & $72 \mathrm{hr}$. & $\begin{array}{l}\text { Heparin } 8 \text { days } \\
\text { S.K. } 24 \mathrm{hr} . \\
\text { S.K. } 48 \mathrm{hr} \text {. }\end{array}$ \\
\hline 16 & $62 M$ & 40 days & $\begin{array}{l}\text { Slowly } \\
\text { progres- } \\
\text { sive }\end{array}$ & \begin{tabular}{|l} 
S.K. $24 \mathrm{hr}$. \\
Heparin 7 day:
\end{tabular} \\
\hline 17 & $54 \quad M$ & $n_{\text {days }}$ & $30 \mathrm{hr}$. & $\begin{array}{l}\text { Heparin } 48 \mathrm{hr} \\
\text { S.R. } 24 \mathrm{hr} . \\
\text { S.K. } 72 \mathrm{hr} \text {. }\end{array}$ \\
\hline 8 & $54 \quad M$ & 16 days & $\begin{array}{l}\text { Slowly } \\
\text { progres- } \\
\text { sive }\end{array}$ & $\begin{array}{l}\text { Heparin } 48 \mathrm{hr} \text {. } \\
\text { S.K. } 12 \mathrm{hr} \\
\text { S.K. } 24 \mathrm{hr} \text {. }\end{array}$ \\
\hline
\end{tabular}

Acute Complicated

\begin{tabular}{|c|c|}
\hline Marked improvement (4 weeks) & Asymptomatic 12 months \\
\hline $\begin{array}{l}\text { No change } \\
\text { Marked improvement } \\
\text { Further marked improvement }\end{array}$ & $\begin{array}{l}\text { Low-dose streptokinase postoperative. } \\
\text { Asymptomatic } 10 \text { months }\end{array}$ \\
\hline No change & $\begin{array}{l}\text { Slow rocovery } \\
\text { Asymptomatic } 5 \text { months }\end{array}$ \\
\hline Marked improvement & \\
\hline $\begin{array}{l}\text { Marked improvement } \\
\text { Further marked improvemen: }\end{array}$ & Asymptomatic 4 months \\
\hline $\begin{array}{l}\text { Moderate improvement } \\
\text { Further improvement }\end{array}$ & Asymptomatic 3 months \\
\hline Marked improvement & Asymptomatic 12 months \\
\hline
\end{tabular}

\begin{tabular}{l|l}
\begin{tabular}{l|l} 
Improved \\
Improved
\end{tabular} & $\begin{array}{l}\text { Marked improvement } \\
\text { Slight further improvemen: }\end{array}$ \\
\hline Improved & -
\end{tabular}

Recurrent Uncomplicated

\begin{tabular}{|c|c|c|}
\hline \\
\hline $\begin{array}{l}\text { Improved } \\
\text { Improved }\end{array}$ & $\begin{array}{l}\text { Marked improvement } \\
\text { Further marked improvement }\end{array}$ & Asymptomatic 12 months \\
\hline $\begin{array}{l}\text { Improved } \\
\text { Improvement maintained } \\
\text { Improvement maintained }\end{array}$ & $\begin{array}{l}\text { Marked improvement } \\
\text { Further improvement } \\
\text { Further improvement }\end{array}$ & $\begin{array}{l}\text { Slow recovery. Asymptomatic } \\
9 \text { months }\end{array}$ \\
\hline $\begin{array}{l}\text { Deteriorated } \\
\text { Improved } \\
\text { Further improvemen: }\end{array}$ & $\begin{array}{l}\text { Moderate improvement } \\
\text { Further improvement }\end{array}$ & $\begin{array}{l}\text { Slow recovery. Asymptomatic } \\
8 \text { months }\end{array}$ \\
\hline $\begin{array}{l}\text { Deteriorated } \\
\text { Improved } \\
\text { Improved } \\
\text { Asymptomatic }\end{array}$ & $\begin{array}{l}\text { Marked improvement } \\
\text { Further slight improvement }\end{array}$ & Asymptomatic 2 month: \\
\hline $\begin{array}{l}\text { Deteriorated } \\
\text { Slight improvemen }\end{array}$ & Slight improvement & Asymptomatic on discharge $t$ weeks \\
\hline $\begin{array}{l}\text { Deterioration } \\
\text { Deterioration after initial } \\
\text { improvement } \\
\text { Improved }\end{array}$ & $\begin{array}{l}\text { Recurrent embolus but improved } \\
\text { peripheral filling }\end{array}$ & $\begin{array}{l}\text { Asymptomatic } 4 \text { weeks after } \\
\text { embolectomy }\end{array}$ \\
\hline $\begin{array}{l}\text { Deterioration } \\
\text { Improvement } \\
\text { Further improvement }\end{array}$ & $\begin{array}{l}\text { Moderate imp:ovemeni } \\
\text { No change }\end{array}$ & Asymptomatic 3 week \\
\hline \multicolumn{3}{|l|}{ Recurrent Complicated } \\
\hline $\begin{array}{l}\text { No change } \\
\text { Death }\end{array}$ & No improvemen: & $\begin{array}{l}\text { Death } 8 \text { days after S.K. from cardiac } \\
\text { infarction and cerebral embolism. } \\
\text { Necropsy-chronic embolic ob- } \\
\text { struction }\end{array}$ \\
\hline $\begin{array}{l}\text { Deteriorated } \\
\text { Improved } \\
\text { Improved }\end{array}$ & Slight improvement & $\begin{array}{l}\text { Death from sepsis } 7 \text { days after S.K. } \\
\text { Minimal evidence of embolism at } \\
\text { necropsy. Rheumatic heart disease }\end{array}$ \\
\hline $\begin{array}{l}\text { Deterioration } \\
\text { No improvement } \\
\text { Slight improvement }\end{array}$ & No improvement & $\begin{array}{l}\text { Death (12 hr. after end of } S . K \text {. therapy) } \\
\text { from cardiac infarction and persis- } \\
\text { tent pulmonary embolism }\end{array}$ \\
\hline
\end{tabular}


adequate, but the adequacy of treatment in the other seven was in question because full details of dosage and control were not available. Eight patients deteriorated clinically while on heparin treatment ; in two of these heparin dosage was thought to be adequate. Pulmonary angiography was repeated after 24 hours of heparin therapy in two patients with recent acute pulmonary embolism (Cases 2 and 3 ) and in one patient with recurrent pulmonary embolism. None of the three patients had complicating cardiac or respiratory disease. There was no haemodynamic or angiographic change in two patients (Tables I and II ; Special Plate, Figs. 1 and 2); the third patient had slight haemodynamic but no angiographic change. One of these patients (Case 2) was subsequently treated with streptokinase and showed marked improvement at 24 hours both on angiographic and on clinical grounds (Hirsh et al., 1967). Treatment had to be stopped after one and a half hours in the other patient (Case 3) because of bleeding from the site of brachial artery puncture ; the third patient was not treated with streptokinase.

\section{Streptokinase Therapy : Dosage and Activity}

The mean loading dose of streptokinase was 160,000 units, with a range of 30,000 to 250,000 units. The maintenance dose per hour ranged from 20,000 to 200,000 units, with a mean of 90,000 units, and the mean time of infusion was 36.5 hours, with a range of $1 \frac{1}{2}$ to 72 hours. Of the 18 patients 16 had evidence of marked systemic fibrinolytic activity, and the remaining two (Cases 2 and 17) were treated with low-dosage infusion to maintain only a mild systemic thrombolytic state because of recent operations (see Chart).

\section{Streptokinase Therapy : Observations}

Fourteen of the 18 patients improved clinically in the 48 -hour period following the beginning of streptokinase therapy. This improvement was maintained in all but one (Case 17), who died seven days later from complications following resection of a carcinoma of the oesophagus. In this case minimal residual pulmonary embolic obstruction was found at necropsy. Of the four who failed to show initial improvement, two subsequently died (Cases 16 and 18) and two required pulmonary embolectomy (Cases 1 and 14), which was successfully performed in both. The indications for embolectomy were cardiac arrest three hours after beginning streptokinase in one (Case 1) and recurrent pulmonary embolism 24 hours after beginning therapy in the other (Case 14). Both fatal cases had recent

TABLE II.-Acute Pulmonary Embolism

\begin{tabular}{|c|c|c|c|c|c|c|c|}
\hline $\begin{array}{l}\text { Case } \\
\text { No. } \\
\end{array}$ & Date & Treatment & $\begin{array}{c}\text { Right Atrium } \\
\text { Mean (a Wave) }\end{array}$ & $\begin{array}{l}\text { Pulmonary Artery } \\
\text { Phasic (Mean) }\end{array}$ & $\begin{array}{l}\text { Cardiac } \\
\text { Index }\end{array}$ & $\begin{array}{c}\mathrm{PO}_{2} \mathrm{~A}-\mathrm{a} \text { Diff. } \\
\text { (mm. } \mathrm{Hg})\end{array}$ & $\begin{array}{l}\mathrm{VD} / \mathrm{VT} \\
(\%)\end{array}$ \\
\hline 1\{ & $\begin{array}{l}22 / 5 / 67 \\
22 / 5 / 67 \\
22 / 6 / 67 \\
17 / 4 / 68\end{array}$ & $\begin{array}{l}\text { S.K. }(2 \overline{\mathrm{hr}}) \text { () } \\
\text { Post-embolectomy }\end{array}$ & $\begin{array}{l}5(9) \\
2(4)\end{array}$ & $\begin{array}{c}31 / 15(22) \\
24 / 11(16) \\
22 / 6(12)(\mathrm{ex} .21)\end{array}$ & $\begin{array}{c}2 \cdot 2 \\
2 \cdot 6 \\
2 \cdot 4(\text { ex. } 2 \cdot 6) \\
-\end{array}$ & $\frac{5}{8-}$ & $\begin{array}{l}53- \\
46- \\
17(34)\end{array}$ \\
\hline 2\{ & $\begin{array}{r}6 / 7 / 67 \\
7 / 7 / 67 \\
8 / 7 / 67 \\
10 / 7 / 67 \\
10 / 4 / 68\end{array}$ & $\begin{array}{l}\text { Hep. }(24 \mathrm{hr} .) \\
\text { S.R. } \\
\text { S.K. }(24 \mathrm{hhr}) \\
\end{array}$ & $\frac{9(12)}{2(4)}$ & $\begin{array}{l}34 / 15(24) \\
38 / 18(24) \\
31 / 14(20) \\
26 / 11(17)\end{array}$ & $\begin{array}{l}3 \cdot 1 \\
3 \cdot 7 \\
4 \cdot 6 \\
4 \cdot 6 \\
-\end{array}$ & $\begin{array}{l}46 \\
40 \\
28 \\
14 \\
16(10)\end{array}$ & $\begin{array}{l}71 \\
63 \\
44- \\
24(21)\end{array}$ \\
\hline 3\{ & $\begin{array}{r}4 / 10 / 67 \\
5 / 10 / 67 \\
24 / 10 / 67 \\
12 / 2 / 68\end{array}$ & $\begin{array}{c}\text { Hep. }(2 \overline{4} \text { hr. }) \\
=\end{array}$ & $\frac{9(12)}{2(5)}$ & $\begin{array}{l}36 / 21(24) \\
43 / 23(30) \\
38 / 14(23)\end{array}$ & $\begin{array}{l}2 \cdot 8 \\
3 \cdot 1 \\
4 \cdot 1\end{array}$ & $\begin{array}{l}55 \\
49 \\
39 \\
11\end{array}$ & ${ }_{43}^{42}=$ \\
\hline 4\{ & $\begin{array}{l}27 / 1 / 68 \\
29 / 1 / 68 \\
1 / 5 / 68\end{array}$ & S.K. $(24$ hr. $)$ & 10 (15) & $\begin{array}{l}54 / 26(31) \\
25 / 12(16)\end{array}$ & $\frac{1 \cdot 2}{=}$ & ${ }_{30 \overline{(15)}}$ & $\overline{7}_{39(35)}$ \\
\hline 5\{ & $\begin{array}{l}2 / 4 / 68 \\
2 / 4 / 68 \\
5 / 4 / 68\end{array}$ & S.K. $(24 \overline{\mathrm{hr}})$. & 12 (15) & $\begin{array}{l}50 / 22(31) \\
28 / 5(13) \\
20 / 7 \text { (15) }\end{array}$ & 二 & 二 & $=$ \\
\hline 6\{ & $\begin{array}{l}10 / 7 / 67 \\
11 / 7 / 67\end{array}$ & S.K. $(2 \overline{4 h r})$. & $9 \stackrel{9(14)}{9}(13)$ & $\begin{array}{l}43 / 20(29) \\
33 / 14(21)\end{array}$ & 二 & 二 & 二 \\
\hline 7 & $\begin{array}{l}13 / 11 / 67 \\
161 / 1 / 67 \\
21 / 2 / 68\end{array}$ & $\begin{array}{l}\text { S.K. }(24 \mathrm{hr} .) \\
\text { S.K. }(48 \mathrm{hr} .) \\
\text { Hep. }(24 \mathrm{hr} .)\end{array}$ & $\bar{z}$ & $\begin{array}{l}33 / 20(25) \\
39 / 14(24)\end{array}$ & $4 \cdot 3$ & $\begin{array}{l}69 \\
42 \\
35\end{array}$ & $50^{-}$ \\
\hline 8\{ & $\begin{array}{l}20 / 7 / 67 \\
21 / 7 / 67\end{array}$ & $\begin{array}{l}\text { S.K. } \\
\text { Hep. }(9 \overline{h r} .) \\
(15 \text { hr. })\end{array}$ & $\begin{array}{l}10(12) \\
9(12)\end{array}$ & $\begin{array}{l}56 / 25(32) \\
54 / 26(34)\end{array}$ & $\bar{z}$ & 二 & ${ }^{35}=$ \\
\hline 9 & $\begin{array}{l}14 / 6 / 67 \\
15 / 6 / 67 \\
7 / 7 / 177 \\
20 / 3 / 68\end{array}$ & S.K. $(24 \overline{h r})$. & 年) & $\begin{array}{c}47 / 17(27) \\
27 / 10(16) \\
28 / 9 \text { (15) (ex. } 27\end{array}$ & $\begin{array}{l}2.3 \\
2.5 \\
3.2 \\
-\end{array}$ & $\begin{array}{r}53 \\
45 \\
22 \\
7\end{array}$ & $\begin{array}{l}65 \\
56 \\
39\end{array}$ \\
\hline 10 & $\begin{array}{l}27 / 10 / 67 \\
28 / 10 / 67 \\
30 / 10 / 67 \\
13 / 11 / 67 \\
15 / 3 / 68\end{array}$ & $\begin{array}{c}\text { S.K. }(24 \mathrm{hr} .) \\
\text { S.K. }(60 \mathrm{hr} .) \\
=\end{array}$ & $\begin{array}{l}0(4) \\
3(7) \\
= \\
=\end{array}$ & $\begin{array}{c}42 / 13(24) \\
31 / 10(20) \\
24 / 11 \text { (17) } \\
=\end{array}$ & $\begin{array}{l}3.6 \\
2.9 \\
=\end{array}$ & $\begin{array}{l}67 \\
60 \\
53 \\
58 \\
37\end{array}$ & $\begin{array}{l}43 \\
36 \\
29 \\
34\end{array}$ \\
\hline 11 & $\begin{array}{c}25 / 11 / 67 \\
27 / 11 / 67 \\
29 / 11 / 67 \\
6 / 12 / 67 \\
6 / 3 / 68\end{array}$ & $\begin{array}{c}\text { S.K. }(2 \overline{h r} .) \\
\text { S.K. }(72 \mathrm{hr} .) \\
=\end{array}$ & $\begin{array}{l}9(13) \\
= \\
=\end{array}$ & $\begin{array}{c}58 / 30(41) \\
38 / 20(26) \\
32 / 16(21) \\
=\end{array}$ & $\begin{array}{l}3.0 \\
2.9 \\
3.9 \\
=\end{array}$ & $\begin{array}{l}71 \\
71 \\
52 \\
5\end{array}$ & ${ }_{23}^{33}=$ \\
\hline 12 & $\begin{array}{l}22 / 4 / 68 \\
23 / 4 / 68 \\
24 / 4 / 68 \\
6 / 5 / 68\end{array}$ & $\begin{array}{l}\text { S.K. }(24 \overline{h r} .) \\
\text { S.K. }(42 \mathrm{hr} .)\end{array}$ & $\frac{7(11)}{1(4)}$ & $\begin{array}{c}43 / 14 \text { (27) } \\
22 / 12 \text { (14) } \\
23 / 7 \text { (13) (ex. 17) }\end{array}$ & 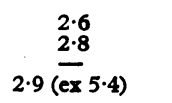 & $\begin{array}{l}63 \\
51 \\
38 \\
13(38)\end{array}$ & $\begin{array}{l}59 \\
29- \\
30(27)\end{array}$ \\
\hline 13\{ & $10 / 4 / 68$ & $\{$ S.K. $(24$ hr. $)$ & 二 & $40 / 19(26)$ & $=$ & 64 & $=$ \\
\hline 14\{ & $\begin{array}{l}22 / 4 / 68 \\
23 / 4 / 68\end{array}$ & S.K. $(24 \overline{h r})$. & $=$ & $\begin{array}{l}41 / 21 \text { (28) } \\
35 / 18(25)\end{array}$ & 二 & $=$ & $\overline{-}$ \\
\hline 15\{ & $\begin{array}{r}9 / 5 / 68 \\
10 / 5 / 68 \\
11 / 5 / 68 \\
7 / 6 / 68\end{array}$ & $\begin{array}{l}\text { S.K. }(24 \overline{h r}) \\
\text { S.K. }(48 \mathrm{hr} .)\end{array}$ & $\begin{array}{l}5(14) \\
=\end{array}$ & $\begin{array}{l}40 / 19(25) \\
3313(19) \\
34 / 11(19) \\
31 / 9(17)\end{array}$ & $\bar{z}$ & $\bar{z}$ & $\bar{z}$ \\
\hline 16\{ & $\begin{array}{l}26 / 7 / 67 \\
27 / 7 / 67\end{array}$ & S.K. $(2 \overline{4} \overline{h r})$ & $\begin{array}{l}4(7) \\
4(10)\end{array}$ & $\begin{array}{l}45 / 24(28) \\
42 / 21(27)\end{array}$ & $\begin{array}{l}1.7 \\
1.9\end{array}$ & $\begin{array}{l}35 \\
36\end{array}$ & $\begin{array}{l}67 \\
61\end{array}$ \\
\hline 17\{ & $\begin{array}{l}22 / 2 / 68 \\
23 / 2 / 68\end{array}$ & S.K. $(24 \overline{h r})$. & $=$ & $\begin{array}{l}64 / 34(40) \\
37 / 22(28)\end{array}$ & 二 & 二 & $=$ \\
\hline 18\{ & $\begin{array}{l}15 / 6 / 68 \\
16 / 6 / 68\end{array}$ & S.K. $(12 \overline{h r})$. & $17(21)$ & $\begin{array}{l}61 / 35(43) \\
52 / 31(37)\end{array}$ & $=$ & $=$ & $=$ \\
\hline
\end{tabular}


myocardial infarction. One patient (Case 16) died from cerebral embolism eight days after treatment, and the other (Case 18) developed a fatal cardiac arrest 40 hours after beginning streptokinase therapy. Necropsy in both cases showed severe pulmonary arterial obstruction by organized thromboembolism, firmly adherent in one but non-adherent in the other. Both had progressive right heart failure, which started with an episode of pulmonary embolism.
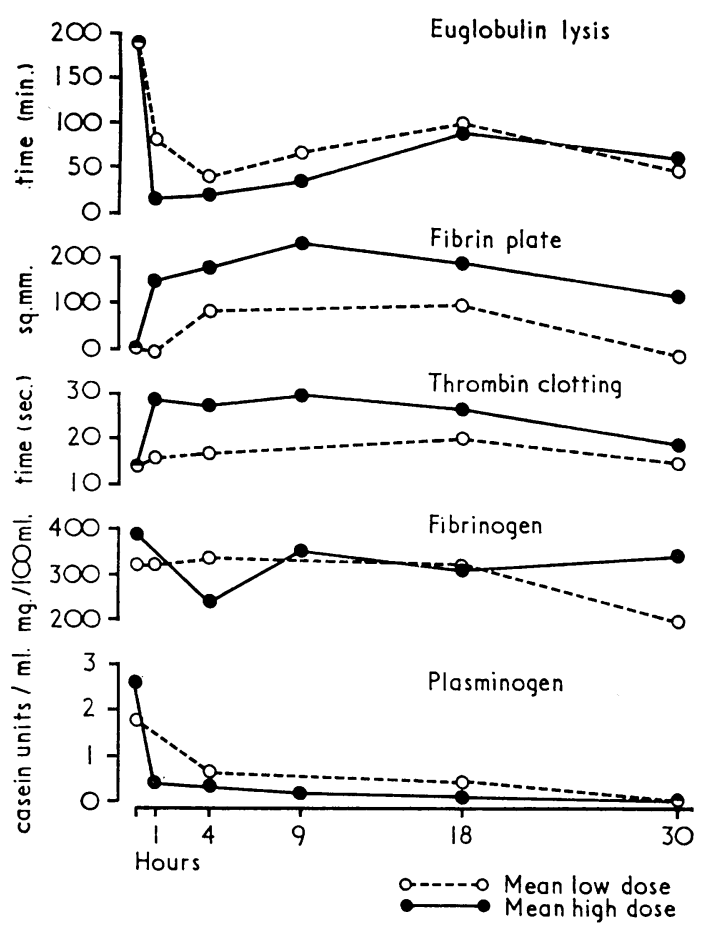

Tests of coagulation and fibrinolytic activity.

Sixteen patients had angiograms repeated 24 hours after streptokinase therapy. Eight showed marked improvement, three moderate improvement, two slight improvement, two no significant change, and one had a recurrent embolus (Table I). Representative angiograms are shown in Figs. 3, 4, and 5 (Special Plate). It is noteworthy that the most pronounced improvement occurred in the first 24 hours (Figs. 4 and 5). Angiographic and haemodynamic improvement noted during or after 24 hours of streptokinase therapy appeared to be less marked in patients with either associated cardiopulmonary disease (referred to as complicated pulmonary embolism) or with clinical evidence of recurrent emboli (Tables I and II). Thus the four patients with recent uncomplicated pulmonary embolism who were treated with streptokinase for 24 hours showed marked angiographic and haemodynamic improvement. In contrast, of the 12 patients with either associated cardiopulmonary disease or recurrent pulmonary embolism restudied at 24 hours, only five showed marked improvement while two showed moderate improvement, two slight improvement, two no change, and in one there was a recurrent embolus.

In both the acute and recurrent groups the fall in mean pulmonary artery pressure following streptokinase was striking and highly significant $(\mathbf{P}=0.05$ in the acute group and $\mathbf{P}<0.01$ in the recurrent group). It is of interest that when the patients were divided into those with complicating associated cardiac or pulmonary disease and those without, the fall in mean pressure in the complicated group was not significant $(0.2<\mathrm{P}<0.3)$. In the seven patients in whom the index of pulmonary vascular obstruction was measured before and after therapy there was a highly significant fall from 10.8 to $7.4(0.01<\mathrm{P}<0.001)$. In contrast in the two patients in whom the index was calculated before and after heparin (Cases 2 and 3) there was a slight fall in one and a slight rise in the other.

\section{Clinical, Haemodynamic, and Lung Function Follow-up}

Fifteen of the 18 patients were alive and free of symptoms 6 weeks to 12 months after treatment with streptokinase. These included the two patients who required pulmonary embolectomy (Cases 1 and 14). Eight patients (Cases 2, 3, 5, 9, 10, 11, 12 , and 15) who survived and were treated with streptokinase without pulmonary embolectomy had follow-up haemodynamic studies three days to one month after beginning streptokinase therapy. Six showed an insignificant rise in pulmonary artery pressure (Cases 2, 5, 9, 10, 12, and 15). Two patients had raised pulmonary arterial pressure four days to three weeks after streptokinase treatment (Cases 3 and 11). One of these (Case 3) had streptokinase for only $1 \frac{1}{2}$ hours and the other had the investigations repeated only four days after starting streptokinase therapy.

Follow-up lung function tests, which included $\mathrm{A}-\mathrm{a} \mathrm{Po}_{2}$ difference and $\mathrm{VD} / \mathrm{VT}$ at rest in nine patients (Cases 1, 2, 3, $4,7,9,10,11$, and 12) and on effort in four (Cases 1, 2, 4, and 12), were performed one to eight months after streptokinase therapy. The VD/VT was normal in all at rest, and in three of the four tested during effort no increase was detected. A mild rise of the $\mathrm{A}-\mathrm{a} \mathrm{PO}_{2}$ difference at rest was found in four of these nine patients (Cases 1, 4, 7, and 10). These results represent a marked improvement on the results of pulmonary function tests performed on diagnosis.

\section{Complications}

Local bleeding from the site of brachial arterial puncture occurred in five patients. More serious bleeding occurred in three patients. One (Case 14) developed cardiac tamponade (diagnosed at pulmonary embolectomy), which was caused by right ventricular perforation during the initial cardiac catheterization. Another (Case 5) developed a large haematoma of the buttock after an inadvertent intramuscular injection, and in the third (Case 3) streptokinase therapy had to be stopped because of bleeding from the site of brachial artery puncture. In addition an unexplained fall in haematocrit of up to $10 \%$ occurred in three other patients (Cases 2, 9, and 12). Mild asymptomatic fever of up to $38.5^{\circ} \mathrm{C}$. followed streptokinase therapy in eight patients. This responded to intravenous corticosteroids. Two other patients developed a temperature of $39^{\circ} \mathrm{C}$. immediately after the second pulmonary angiogram; this may also have been partly due to streptokinase therapy.

\section{Discussion}

The majority of pulmonary embolism episodes do not cause haemodynamic changes severe enough to give rise to symptoms, and are recognized clinically only when they produce features of pulmonary infarction. Untreated patients with these minor embolic episodes may die from further embolism or from propagation of thrombi from the initial embolus. These sequelae are considerably reduced by adequate heparin therapy (Thomas, 1965).

Sudden pulmonary embolism severe enough to produce pulmonary hypertension may cause death quickly from the consequences of pulmonary arterial obstruction. Death from a single embolic episode may occur immediately or within the first one to two hours, and thus before the diagnosis can be confirmed ; or it may occur in the next 24 to 48 hours (Rosenberg et al., 1964). While recurrent embolism or propagation of the embolus may be responsible for some of these delayed deaths, it is probable that many are caused by the direct haemodynamic result of the initial embolic obstruction. 


\section{J. HIRSH ET $A L .:$ STREPTOKINASE THERAPY IN ACUTE MAJOR PULMONARY EMBOLISM}
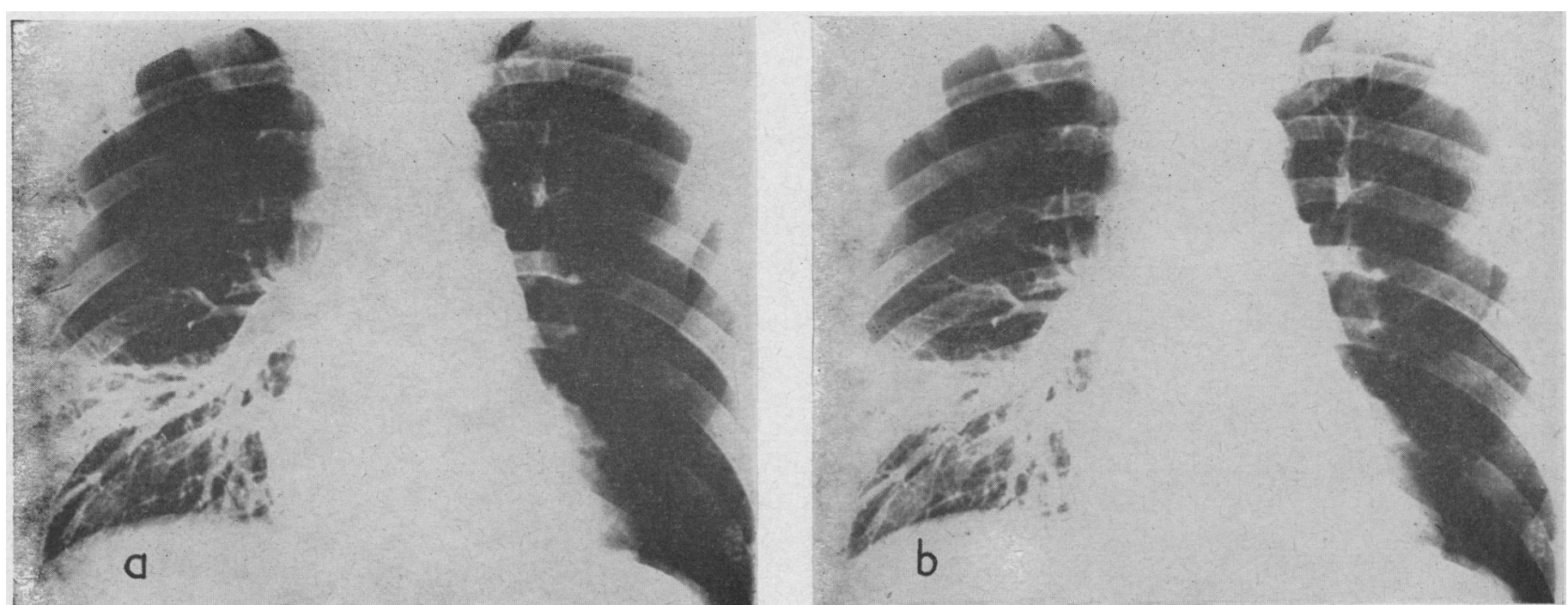

Fig. 1.-Case 2. Pulmonary angiograms (a) before treatment with heparin and (b) after 24 hours of treatment with heparin. Severe obstruction, with flow confined to the right lower lobe. There is no significant change after treatment with heparin.
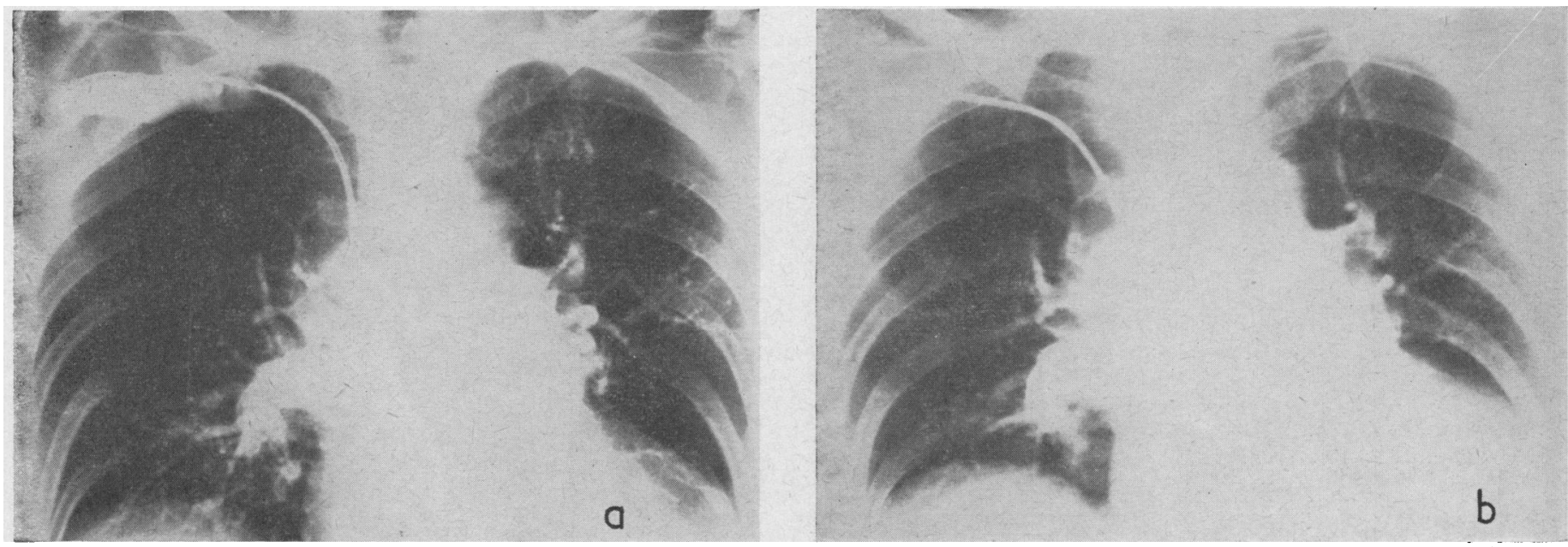

Fig. 2.-Case 3. Pulmonary angiograms (a) before treatment with heparin and (b) after 24 hours of treatment with heparin. Bilateral filling defects in major pulmonary arteries. There is no significant change after heparin therapy.
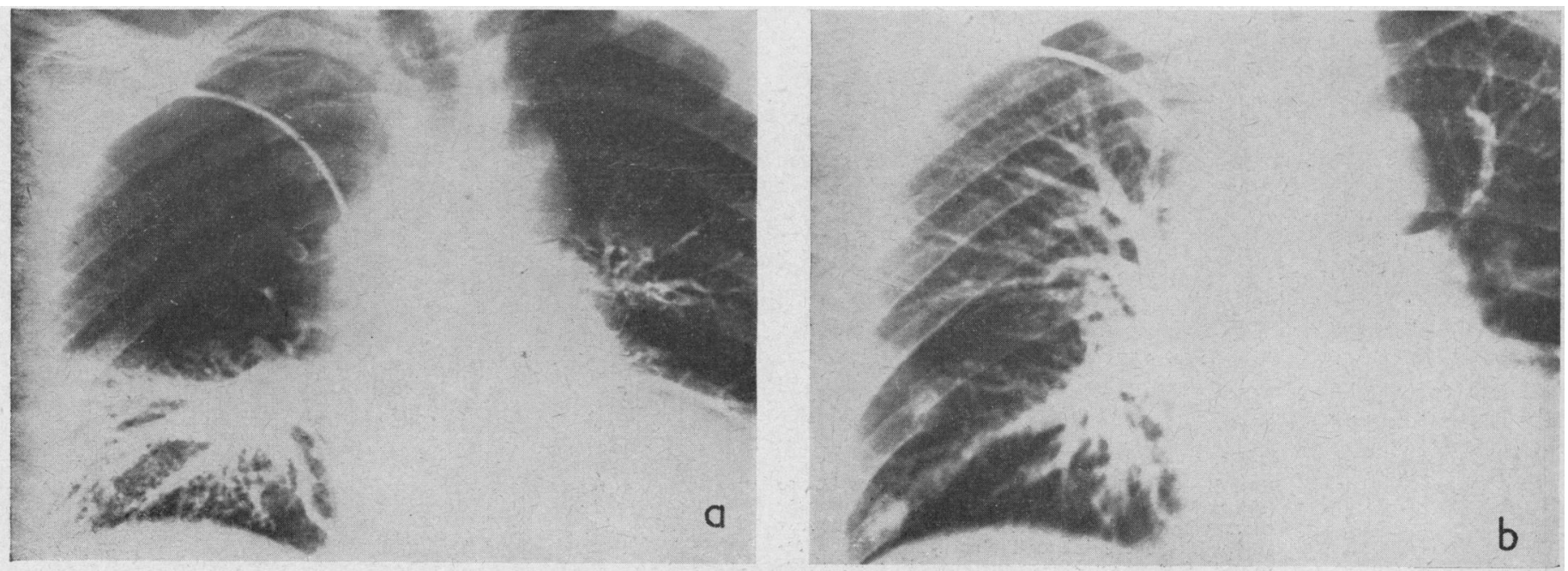

FIG. 3.-Case 7. Pulmonary angiograms (a) before treatment with streptokinase and (b) after 24 hours of streptokinase therapy. Severe pulmonary artery obstruction which resolved, particularly on the right side, after streptokinase therapy. 


\section{J. HIRSH ET $A L .:$ STREPTOKINASE THERAPY IN ACUTE MAJOR PULMONARY EMBOLISM}

Fig. 4.-Case 11. Pulmonary angiograms before (a) and after 24 hours (b) and 48 hours (c) of streptokinase therapy. Severe bilateral obstruction showing moderate degree of resolution at 24 hours, with further improvement at 48 hours.

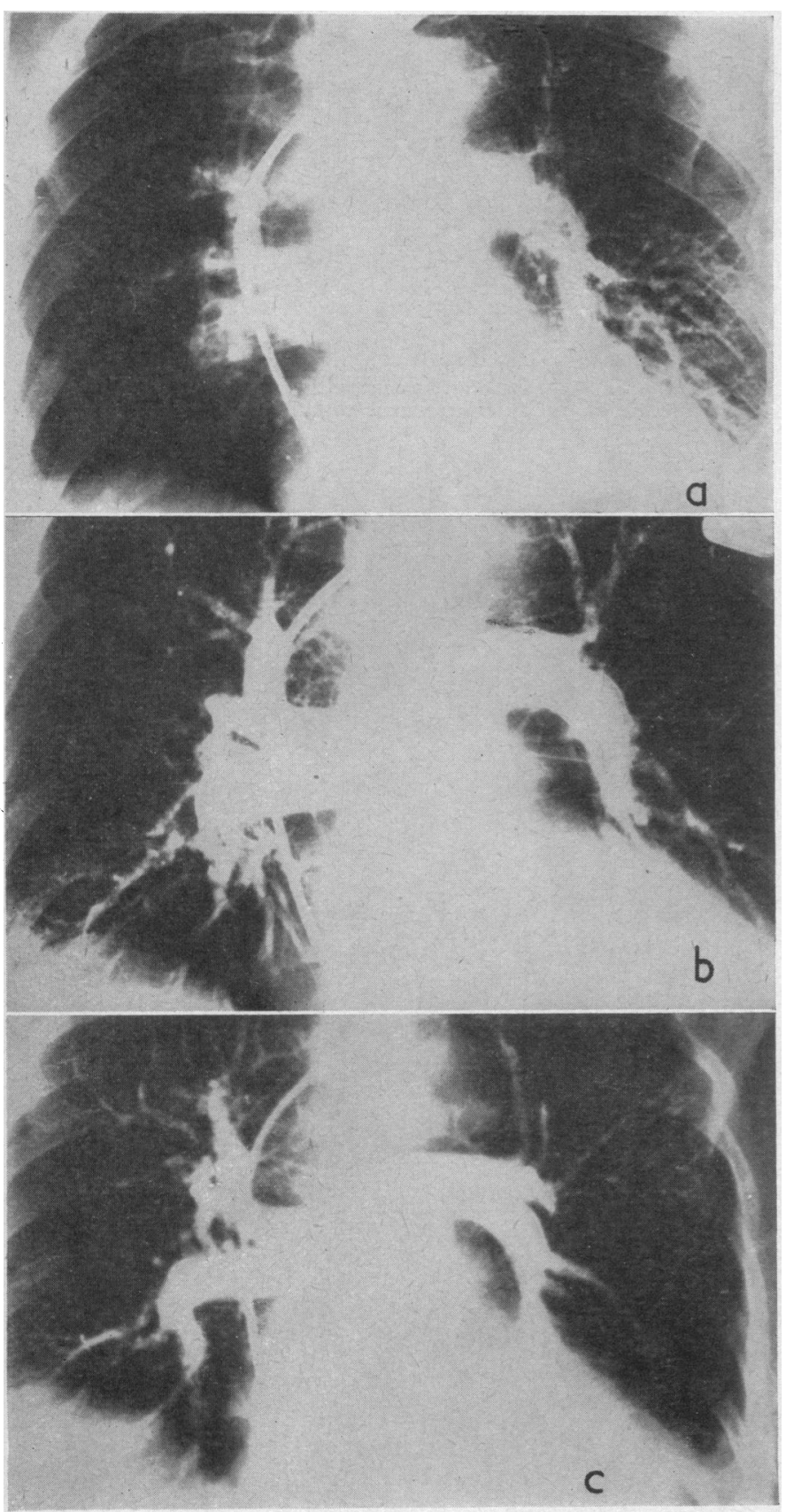

FIG. 4

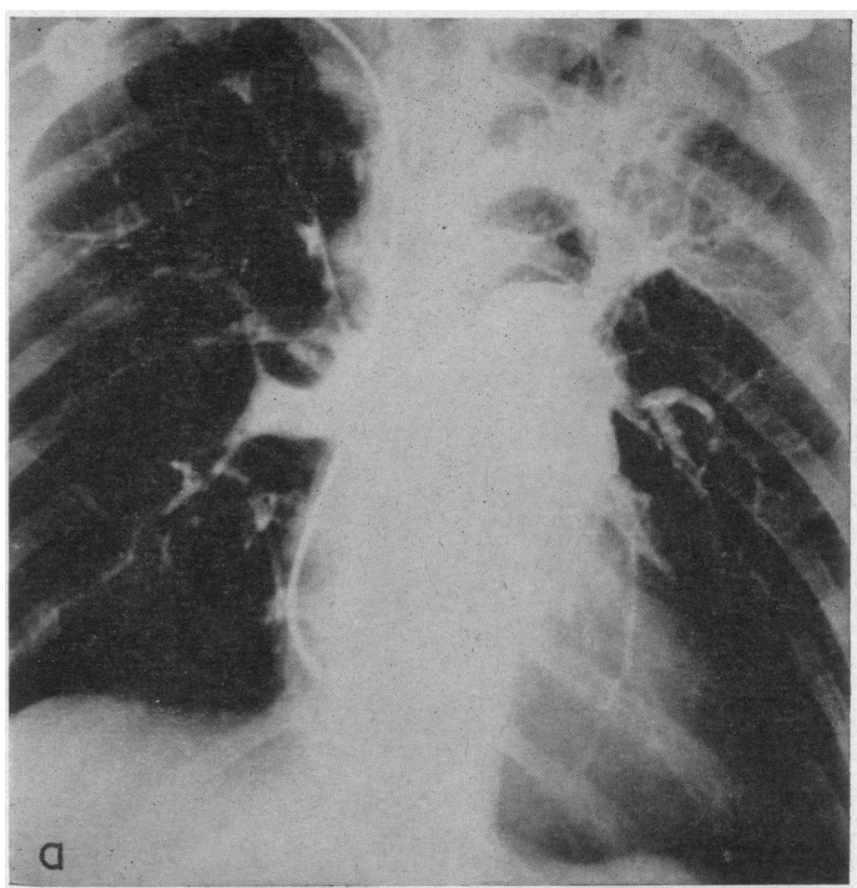

FIG. 5.-Case 12. Pulmonary angiograms before (a) and after 24 hours (b) of streptokinase therapy and $(c) 20$ days after streptokinase therapy stopped. Severe bilateral obstruction which resolved after streptokinase therapy. Further slight improvement 20 days later.

C

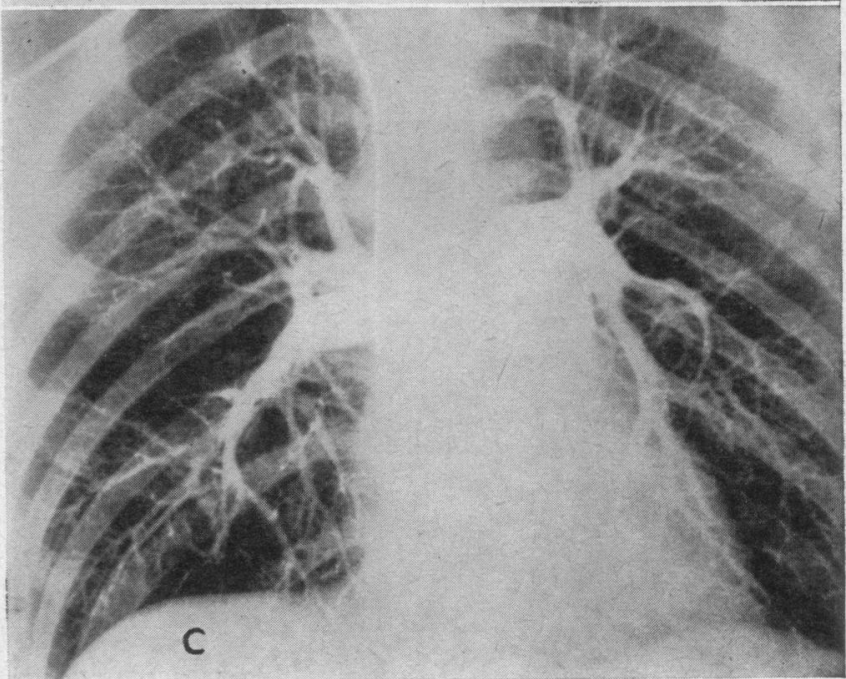

Fig. 5 
Though spontaneous resolution of heparin-treated massive pulmonary embolism has been described in man (Emanuel et al., 1966 ; Fred et al., 1966), the rate of resolution in the first 24 to 48 hours after the episode is not known. However, the findings reported by Chait et al. (1967) suggest that angiographically demonstrable spontaneous resolution in the first 24 hours is relatively uncommon. Thus these authors found that only 5 out of 20 patients with major pulmonary embolism showed significant resolution seven or more days after the initial episode. Furthermore, in the present series the only three patients studied after 24 hours of heparin treatment showed no angiographic improvement, and there was a fall in pulmonary arterial pressure in one.

Our experience with streptokinase in the treatment of acute major pulmonary embolism has been encouraging. Thus all patients in the series had major pulmonary embolism severe enough to be considered for pulmonary embolectomy ; yet only one failed to survive the initial treatment period and two others subsequently died seven and nine days after streptokinase therapy. All three patients had complicating cardiac disease, and one died from causes unrelated to pulmonary embolism. Two patients developed complications and required pulmonary embolectomy; it is possible that thrombolytic therapy may have contributed to these complications. Thus in one patient the operative findings suggested that the cardiac arrest which occurred during streptokinase therapy may have been caused by obstruction consequent on fragmentation of the bifurcation embolus, and in the other streptokinase may have been responsible, at least in part, for the recurrent embolus.

Eleven of the remaining 13 patients were restudied 24 hours after streptokinase therapy. Eight showed marked improvement and three moderate improvement at 24 hours. In most patients who had further angiograms at 48 or 72 hours it was evident that maximum improvement had occurred in the first 24 hours (Fig. 4).

It is of interest that only two patients treated with streptokinase showed no improvement angiographically at 24 hours and that both had organized emboli at necropsy. As might be predicted from other investigations (Johnson and McCarty, 1959 ; Genton and Wolf, 1967b) the most impressive results were obtained in patients who had streptokinase therapy within two to three days of the first clinical episode of pulmonary embolism. However, surprisingly good results were obtained in a number of patients who on clinical grounds were suspected of having recurrent severe embolism (Figs. 4 and 5). Though it seems most unlikely that thrombolytic therapy would accelerate resolution of anything but the more recent embolic episodes, these observations emphasize the difficulty of assessing the age of embolism, and hence the potential responsiveness, on clinical grounds.

The most common complication of streptokinase therapy was bleeding ; this was usually not significant, and was associated with trauma. Overt haemorrhage in three patients was clearly responsible for a fall in haematocrit, and it was presumed that the fall in haematocrit which occurred in the other three patients was caused by bleeding into areas of pulmonary infarction since all three developed pleuritic pain and a pleural effusion 48 to 72 hours after beginning streptokinase therapy. An asymptomatic fever occurred in eight patients, but this was not a troublesome symptom and responded to corticosteroids. This is in keeping with the experience of other workers who have used European preparations (Schmutzler et al., 1966 ; Verstraete et al., 1966) and contrasts with the severe reactions described with earlier preparations of streptokinase (Tillett et al., 1955).

The results of this and other studies suggest that thrombolytic therapy is a practical form of treatment in patients with acute major pulmonary embolism (Hirsh et al., 1967 ; Sasahara et al., 1967 ; Sautter et al., 1967 ; Tow et al., 1967). By leaving a catheter in a main pulmonary artery after diagnostic pulmonary angiography it is possible to carry out serial haemodynamic and angiographic studies. This is helpful in assessing progress, and, even more important, it facilitates the performance of emergency pulmonary angiography should this be necessary (as in Case 14). Non-fatal complications occurred with the initial diagnostic pulmonary angiogram in two patients; one had a perforation in the right ventricular wall during the initial diagnostic angiogram, and in the other an episode of atrial flutter followed angiography.

The incidence of chronic pulmonary hypertension following an acute pulmonary embolic episode is unknown. It is generally assumed, on clinical grounds, that in most patients who survive an initial acute episode of pulmonary embolism and who are treated with anticoagulants the embolus eventually resolves. While this view is supported by some angiographic studies, the relatively high incidence of organized obstructing thromboemboli at necropsy cannot be overlooked (Hollister and Cull, 1956 ; Orell, 1962). Though our period of follow-up is limited it would appear from the early resolution of pulmonary hypertension and from the follow-up clinical and pulmonary function data that the cases described in this report were not left with significant resicual pulmonary embolic disease.

\section{Plan of Treatment}

The results of this study suggest that streptokinase accelerates resolution of pulmonary emboli; however, further investigations comparing the effects of heparin and streptokinase on the early clinical, haemodynamic, and angiographic course of major pulmonary embolism are required. It would be premature to define the role of thrombolytic therapy in the management of major pulmonary embolism until such studies are performed. However, if therapy and monitoring facilities are available, the following recommendations based on the experience obtained may be made. The diagnosis of major pulmonary embolism should be confirmed by pulmonary angiography. It is then preferable to transfer the patient to a ward with facilities for monitoring of cardiac rhythm. Treatment with intravenous heparin 10,000 units statim and 25,000 units for 24 hours by continuous intravenous infusion, oxygen, and digoxin is begun. Isoprenaline by continuous intravenous infusion is given if required (McDonald et al., 1968). The surgical team is consulted and bypass facilities are prepared if the case is judged on clinical grounds to be severe. If large filling defects have been demonstrated in major pulmonary vessels the angiography catheter is left in situ in the pulmonary artery and used for further angiography.

Streptokinase is infused through the pulmonary artery catheter for at least 24 hours ; the loading dose is calculated according to the streptokinase resistance test, and the maintenance dose determined by serial tests of fibrinolytic activity. However, should this test not be readily available a loading dose of 250,000 units given over half an hour followed by 100,000 units per hour is begun. Our findings, in keeping with those reported by Schmutzler et al. (1966), suggest that this dosage regimen produces rapid and sustained thrombolytic activity in most patients. Streptokinase is contraindicated in patients in whom there is a danger of local haemorrhage-for example, a proved peptic ulcer. While recent surgery may pose a theoretical contraindication for streptokinase because of the possibility of wound breakdown and haemorrhage, a carefully controlled rate of infusion sufficient to produce no more than a mild systemic effect may prove to be acceptable.

The patient's progress is assessed on clinical grounds, and, by following serial measurements of mean $\mathrm{PA}_{\mathrm{A}}$ pressure, $\mathrm{A}-\mathrm{a} \mathrm{PO}_{2}$ difference, and if these criteria and angiography show improvement, heparin infusion is continued for 10 days at least, and followed by oral anticoagulant therapy for three to six months (O'Sullivan et al., 1968). Failure of thrombus dissolution in 24 hours suggests that the embolism is not of recent origin, and if it is severe on clinical, haemodynamic, and 
angiographic grounds embolectomy should be considered. Alternatively, continued streptokinase and/or heparin therapy is justified if the obstruction is predominantly distal rather than proximal or if recent cardiac infarction is suspected. Pulmonary embolectomy may be necessary in patients whose circulation is failing rapidly or if conservative measures, including streptokinase and isoproterenol infusion, fail to restore and maintain a satisfactory circulation at any time following diagnosis. Although pulmonary embolectomy may be lifesaving, the indications for operation are of ten complicated by the fact that many patients are elderly and have associated cardiac or pulmonary disease.

This investigation was supported by a grant from the National Heart Foundation of Australia. Exercise studies were made possible by a grant from the St. Vincent's School of Medical Research. We are grateful to the medical, nursing, and technical staff of St. Vincent's Hospital, to Mr. J. K. Clarebrough, thoracic surgeon, St. Vincent's Hospital, and to Mr. K. N. Morris, honorary thoracic surgeon, Alfred Hospital, for their assistance and co-operation; also to Professor G. C. de Gruchy for constructive comments. The streptokinase (Streptase) was kindly supplied by Australian Hoechst Limited.

Requests for reprints should be sent to J. Hirsh, University Department of Medicine, St. Vincent's Hospital, Fitzroy, Victoria, Australia 3065.

\section{REFERENCES}

Browse, N. L., and James, D. C. O. (1964). Lancet, 2, 1039.

Chait, A., Summers, D., Krasnow, N., and Wechsler, B. M. (1967) Amer. ₹. Roentgenol., 100, 364

Comroe, J. H., Forster, R. E., Dubois, A B., Briscoe, W. A., and Carlsen, E. (1962). The Lung : Clinical Phvsiology and Pulmonary Function Tests, 2nd ed. Chicago.

Emanuel, D. A., Sautter, R. D., and Wenzel, F. J., (1966). F. Amer. med Ass., 197, 924.

Fred, H. L., Axelrad, M. A., Lewis, J. M., and Alexander, J. K. (1966). f. Amer. med. Ass., 196, 1137.

Genton, E. and Wolf, P S (1967a), 7. Lab. clin. Med, 70, 311.

Genton, E., and Wolf, P. S. (1967b). Circulation, 35, Suppl. No. 2

Hirsh, J., Hale, G. S., MLDonald, I. G., McCarthy, R. A., and Cade,

Jollister, L. E., and Cull, V. L. (1956). Amer F. Med., 21, 312.

Johnson, A. J., and McCarty, W. R. (1959). Y. clin. Invest., 38, 1627

McDonald, I. G, Hirsh, J., Hale, G. S., Cade, J. F., and McCarthy, R. A (1968). Med. . Aust. In press.

Orell, S. R. (1962). Acta med. scand., 172, 473.

O'Sullivan, E. F., Hirsh, J., McCarthy, R. A., and de Gruchy, G. C. (1968). Med. \%. Aust., 2, 153.

Rosenberg, D. M. L., Pearce, C, and McNulty, J. (1964). F. thorac. cardiovasc. Surg., 47, 1

Sasahara, A. A., Cannilla, J. E., Belko, J. S., Morse, R. L., and Criss, A. J. (1967). New Engl. F. Med., 277, 1168.

Sautter, R. D., Emanuel, D. A., and Wenzel, F. J. (1967). Ann. thorac Surg., 4, 95 .

Schmutzler, R., et al. (1966). Germ. med. Mth., 11, 308.
Thomas, D. P. (1965). New Engl. f. Med., 273, 885.

Tillett, W. S., Johnson, A. J., and McCarty, W. R. (1955). F. clin

Invest., 34, 169. W. W. W., and Holmes, R. A. (1967). New Engl. F. Med., 277, 1161 .

Verstraete, M., Vermylen, J., Amery, A., and Vermylen, C. (1966). Brit. med. F., i, 454.

\title{
Gastric Ulceration Occurring during Indomethacin Therapy*
}

\author{
R. T. TAYLOR, M.B., M.R.C.P. ; E. C. HUSKISSON, M.B., M.R.C.P. ; G. H. WHITEHOUSE, M.B., M.R.C.P. \\ F. DUDLEY HART, M.D., F.R.C.P. ; D. H. TRAPNELL, M.A., M.D., M.R.C.P., F.F.R.
}

[With Special Plate Between Pages 732 and 733]

Cummary : Dyspeptic symptoms, gastrointestinal bleed$\checkmark$ ing, or the development of anaemia without dyspepsia in patients treated with indomethacin may be manifestations of peptic ulceration. Such manifestations occur with suppositories as well as with capsules. The ulcers in the present series tended to be prepyloric, and often aroused the suspicion of malignancy. Symptoms were promptly relieved and radiological healing occurred rapidly after withdrawal of the drug.

\section{Introduction}

Indigestion and occasional peptic ulceration are side-effects that may occur during indomethacin therapy (Lövgren and Allander, 1964 ; Lockie and Norcross, 1966 ; Boardman and Hart, 1967). Hart (1965) drew attention to the occurrence of gastric ulceration with radiological features suggesting malignancy, and we here report seven such cases that have occurred in patients receiving indomethacin. Three other cases of gastric ulceration are also reported and discussed.

\section{Case 1}

\section{Case Reports}

A 51-year-old clerk had had rheumatoid arthritis since 1959. She was started on oral indumethacin in August 1967. Three

- From Westminster Hospital, London S.W.1. months later she developed headaches, dizziness, and pounding in the head, and stopped taking indomethacin. She was found to be anaemic (haemoglobin 60\%), and a barium meal examination revealed a prepyloric ulcer. She had had no indigestion at any time. One month after stopping indomethacin she was asymptomatic, and a barium meal examination showed complete healing of the ulcer. She remained symptom-free six months later.

\section{Case 2}

A 48-year-old shopkeeper had had rheumatoid arthritis since 1964. He was started on oral indomethacin in May 1965, and continued taking 150-250 mg. daily for two years. In May 1967 he was admitted to hospital as an emergency case, having vomited a large amount of blood. One month previously he had developed epigastric pain, but had been unable to reduce the dosage of indomethacin because of increasing stiffness. He had had no indigestion before this time. A barium meal examination showed a shallow prepyloric ulcer. He was given no further indomethacin by mouth, but was started on suppositories (100 mg. twice daily). A barium meal examination one month later showed only a very shallow crater. A further barium meal examination in September 1967 showed the ulcer to be larger. The appearance was said to be suspicious of malignancy. Indomethacin suppositories were withdrawn, and three months later the ulcer was completely healed. He remained symptom-free six months later.

\section{Case 3}

A 61-year-old electrical inspector was admitted to hospital in September 1965, having had rheumatoid arthritis for 14 months. 